\author{
KAROLINA KULIŃSKA-JACHOWSKA \\ ORCID: 0000-0002-0143-8368 \\ Uniwersytet Wrocławski
}

\title{
INTEGRALNOŚĆ PRAWA ADMINISTRACYJNEGO. PERSPEKTYWA POLSKA, RED. JAN ZIMMERMANN, WOLTERS KLUWER POLSKA, WARSZAWA 2019, 374 SS.
}

Monografia pt. Integralność prawa administracyjnego. Perspektywa polska, wydana pod redakcją naukową Jana Zimmermanna, jest wynikiem badań i refleksji naukowych dokonanych nad tytułowym zagadnieniem przez pracowników Katedry Prawa Administracyjnego na Wydziale Prawa i Administracji Uniwersytetu Jagiellońskiego. Sformułowanie „refleksja naukowa” nie zostało użyte tutaj w sposób dekoracyjny. Praca krakowskich akademików to bowiem aktualny głos w dyskusji nad tożsamością metodologiczną prawa administracyjnego ${ }^{1}$. Autorzy w miejsce krytycznej, retrospektywnej analizy tego problemu przedstawiają oryginalny postulat i kierunek badawczy, a także metodologiczny, polegający na tym, aby charakteryzować daną dziedzinę prawa, prowadzić w jej ramach szczegółowe badania i formułować tezy teoretyczne w oparciu o jej integralność i o analizę jej pogranicza. Praca została opublikowana równolegle w dwóch wydaniach w języku polskim i angielskim. Fakt ten może świadczyć o zamierzeniu autorów, aby, oprócz wniesienia twórczego wkładu w określenie kryteriów-znaczników granic polskiego prawa administracyjnego, ich praca stała się ogólnodostępnym źródłem wiedzy o specyfice polskiego prawa administracyjnego i podstawą do prowadzenia badań porównawczych.

Recenzja przedstawia uwagi dotyczące obu wydań książki. Przyszłego czytelnika powinny zainteresować spostrzeżenia oparte na równoległej lekturze i analizie obu wersji językowych. Niedawne zmiany legislacyjne w prawie o szkolnictwie wyższym stały się katalizatorem zdobywania biegłości w publikowaniu wyników badań w językach obcych. W kontekście nauk prawnych oznacza to dbałość o przedstawianie swoich myśli w języku obcym w sposób przystępny

${ }^{1} \mathrm{O}$ wkładzie przedstawicieli prawa administracyjnego w rozwój metodologii nauk prawnych zob. na przykład D. Van Kędzierski, Metodologia i paradygmat polskich szczegółowych nauk prawnych, „Transformacje Prawa Prywatnego” 2018, nr 3. 
i zrozumiały dla badaczy pozostających nieraz niezwykle daleko poza zasięgiem rodzimego kontekstu prawnego i kulturowego. Weryfikacja tego, czy — a jeżeli tak, to w jaki sposób - założony cel został w publikacji osiągnięty, niezależnie od jej wyników, będzie stanowić inspirację warsztatową dla autorów prac naukowych tworzących w językach obcych. W tym miejscu konieczne jest dodatkowe zastrzeżenie. Wydanie w języku angielskim nie zawiera dodatkowych informacji o udziale tłumaczy lub anglojęzycznych redaktorów w przygotowaniu publikacji. $\mathrm{Z}$ tego powodu przyjęto, że obie wersje językowe zostały przygotowane przez autorów i to oni odpowiadają za poszczególne decyzje tłumaczeniowe w ramach przygotowanych rozdziałów i spójność terminologiczną w całości pracy.

Monografia została podzielona na trzy części tematyczne, które obejmują łącznie trzynaście rozdziałów. Klamrę redakcyjną tworzą wspólny wstęp i podsumowanie. We wstępie zakreślono ramy publikacji przez sformułowanie czterech zastrzeżeń. Po pierwsze, zgodnie z tytułem rozważania dotyczą jedynie polskiego prawa administracyjnego i nie obejmują badań porównawczych, choć wydanie anglojęzyczne może stanowić dla nich źródło. Po drugie, publikacja nie aspiruje do miana wyczerpującej tytułowe zagadnienie, jest jedynie próbą wprowadzenia nowej, w ocenie autorów dotąd niewykorzystanej, metody badania prawa administracyjnego. Po trzecie, zwrócono uwagę na wielość kryteriów podziału systemu prawa w piśmiennictwie. Wyznaczone przez autorów obszary pogranicza prawa administracyjnego są zatem ze swej istoty zmienne. Po czwarte, dowiadujemy się, że publikacja ma konstrukcję pośrednią między monografią naukową a zbiorem esejów naukowych powiązanych luźno wspólnym motywem.

Pierwsza część publikacji poświęcona została pojęciom integralności i pogranicza prawa administracyjnego. Otwiera ją rozdział Przemysława Wszołka zatytułowany Istota $i$, rodzaje” integralności prawa administracyjnego. Autor trafnie zauważa, że problematyka kryteriów wyodrębnienia prawa administracyjnego ma charakter uniwersalny. Emancypacja tej gałęzi prawa przebiegała w poszczególnych porządkach prawnych w sposób odmienny. W związku z tym w ocenie autora rodzimy system prawa administracyjnego można określić właśnie jako integralny, ponieważ zajmuje miejsce pośrednie między modelem anglosaskim, w którym prawo administracyjne funkcjonuje jako część prawa powszechnego, a autonomicznym modelem francuskim. W tym znaczeniu integralność oznacza wewnętrzną spójność i jednolitość norm prawa administracyjnego, stanowiącą o jego odrębności, ale już nie o samodzielności względem pozostałych gałęzi prawa. Integralność przedstawiono jako pojęcie dwuwymiarowe (mające „wymiar zewnętrzny” i „,wymiar wewnętrzny”). Identyfikacja znamion prawa administracyjnego składających się na oba te - nierozerwalnie z sobą powiązane - wymiary jest elementem koniecznym procesu indywidualizacji tej gałęzi prawa. Zdaniem autora integralność ma także swój wymiar aksjologiczny — nie tylko pełni funkcję ,idei porządku”, lecz także pozostaje „wartością, którą należy chronić”. 
Postulat integralności nie jest w pełni realizowany ze względu na mnogość czynników utrudniających wewnętrzne zintegrowanie prawa administracyjnego. Wśród nich autor wymienia między innymi szerokość i heterogeniczność regulacji, niestaranność i niekonsekwencję prawodawcy, głębokość i multicentryczność źródeł prawa oraz brak kodyfikacji. Podkreślono także wpływ dydaktyki i doktryny na wewnętrzną stratyfikację tej gałęzi prawa. Autor podkreśla, że potrzeba wyodrębnienia prawa administracyjnego nie jest jedynie zagadnieniem teoretycznym, lecz wynika z praktyki prawniczej. Dystynkcja prawa administracyjnego ma bowiem wpływ na proces wykładni, sytuację podmiotów administrowanych (pewność prawa), naukę prawa administracyjnego (zabieg ten pozwala wyznaczyć pole refleksji naukowej) oraz dogmatykę przez dobór właściwych metod i technik prawodawczych. Może się to odbywać za pomocą typologii lub klasyfikacji. W przypadku tej ostatniej ważną rolę odgrywa postrzeganie kryteriów wyodrębniania, które nie jest jednolite w literaturze. Autor przekonuje, że chodzi tu nie o kryterium logiczne, lecz o poszukiwanie znamion swoistych wyłącznie dla prawa administracyjnego, które składają się na jego ,jurydyczną tożsamość”.

Koncepcja integralności powinna uwzględniać zmienność czasoprzestrzenną prawa, wobec czego rozróżniono integralność statyczną (apragmatyczną) i integralność dynamiczną (pragmatyczną). To ujęcie obrazuje kolejną funkcję czy też postać integralności jako narzędzia badawczego. Przechodząc do zagadnień szczegółowych, autor wymienia kolejno czynniki wzmacniające i osłabiające integralność wewnętrzną i zewnętrzną prawa administracyjnego, zwracając uwagę między innymi na zjawiska takie jak wspólne podstawy aksjologiczne i poszanowanie zasad repartycji przez ustawodawcę (czynniki wzmacniające) oraz wyodrębnianie się dziedzin szczególnych tej gałęzi i multicentryczność systemu prawa (czynniki osłabiające).

Użyteczność integralności jako „idei porządku prawa administracyjnego" ma się przejawiać tym, że wyjaśnia konieczność badania jego poszczególnych elementów w sposób zintegrowany, jako części składowych prawa administracyjnego i całego (krajowego) systemu prawa. Wprowadzenie do dyskursu pojęcia-postulatu integralności może stanowić odpowiedź na potrzeby dogmatyki wynikające $\mathrm{z}$ tego, że prawo administracyjne nie ma własnej metody badawczej. Jednocześnie jednak autor przekonuje, iż koncepcja ta jest nieswoista i daje się zastosować na gruncie innych gałęzi prawa.

W rozdziale drugim autorstwa Mariusza Kotulskiego pod tytułem Istota i funkcje pogranicza polskiego prawa administracyjnego zawarto charakterystykę drugiego pojęcia przewodniego publikacji. Punktem wyjścia jest konstatacja dotycząca braku ostrego podziału między dyscyplinami prawniczymi w polskiej dogmatyce. Zjawisko to pogłębia kształtowanie się coraz to nowszych subdyscyplin, takich jak prawo energetyczne czy prawo ochrony danych osobowych. Z kolei zarówno sama kategoria systemu prawa, jak i wyodrębnianie poszczególnych 
dyscyplin przez konieczność precyzyjnego wytyczania ich granic wiążą się z pozytywistycznym ujęciem prawa. Problematyka pogranicza dyscyplin jest wpisana w ideę integralności zewnętrznej, gdyż spójność całego systemu obowiązującego prawa sprawia, że istnieją elementy styczne czy wręcz wspólne dla kilku, a nawet wszystkich dyscyplin prawniczych. Podstawowym założeniem badania pogranicza jest zatem nieautonomiczność poszczególnych dyscyplin. Kategoria pogranicza zaś pozostaje $\mathrm{w}$ opozycji do idei integralności, wytyczając w ten sposób zakres elementów swoistych dla danej dziedziny. Autor odrzuca podział na dyscypliny według przedmiotu regulacji jako nieprzydatny i nadmiernie zawężający pole badawcze.

Przedmiotem dyscyplin prawniczych jest problematyka systematyzacji, interpretacji i walidacji prawa, a podmiotami zmierzającymi do zachowania spójności systemu prawa $\mathrm{w}$ procesie jego stanowienia i stosowania są odpowiednio prawodawca, interpretator i przedstawiciele doktryny. Autor stawia interesującą tezę, zgodnie z którą taki układ uczestników dyskursu pozwala na zachowanie spójności systemu w ujęciu korekcyjno-kontrolnym w przypadku dysfunkcyjności maksymalnie jednego z podmiotów (na przykład przez korektę błędów ustawodawcy w drodze interpretacji tekstu prawnego).

Wskazano, że wytyczanie granic regulacji normatywnej jest istotnym aspektem stanowienia prawa. Granice wyznaczają cel i metoda, na której wybór wpływ mają determinanty zewnętrzne i wewnętrzne. Brak poszanowania przedmiotu, metod i zasad stanowienia prawa prowadzi do instrumentalizacji prawa i zagraża integralności poszczególnych jego gałęzi. Wśród czynników dezintegrujących prawo administracyjne dodatkową uwagę poświęcono zagadnieniom braku kodyfikacji, wpływu prawa Unii Europejskiej i postępowaniom hybrydowym. Rozdział kończą uwagi dotyczące tytułowych funkcji pogranicza prawa administracyjnego. Fragment ten stanowi niestety niewielką część całego rozdziału (jedna strona) i ogranicza się do wymienienia funkcji wspólnych dla pogranicza i systemu prawa oraz funkcji swoistych dla pogranicza prawa administracyjnego, bez ich szczegółowego omówienia. W zakończeniu autor podkreśla, że budowanie integralności poszczególnych dyscyplin nie musi dokonywać się każdorazowo przez wytyczanie granic i wymaga odniesienia także do procesów stosowania i stanowienia prawa, jego zasad i aksjologii. Należy zgodzić się z autorem, że dyskusja nad tymi zagadnieniami powinna być aktualizowana wraz z postępem technokratyzacji prawa.

Podział integralności na wewnętrzną i zewnętrzną wyznacza dalszą konstrukcję publikacji. Część drugą poświęcono problematyce integralności wewnętrznej prawa administracyjnego. Składa się ona z czterech rozdziałów. Rozdziały trzeci i czwarty dotyczą elementów sprzyjających wewnętrznemu integrowaniu się prawa administracyjnego i ukazują to zagadnienie z dwóch perspektyw. W rozdziale trzecim Wojciech Jakimowicz przedstawia je od strony teoretycznej. W tym celu posługuje się metaforą „gmachu prawa”, w którym fundamenty tworzą normy Konstytucji. Do elementów sprzyjających integralności („stabilizujących konstrukcję" tej gałęzi prawa) zalicza metodę władczą regulacji i bezwzględne obo- 
wiązywanie przepisów prawa administracyjnego. Omówiona została również rola zasad prawa i postępowania administracyjnego. Wyeksponowano rolę samorządu lokalnego i doniosłość zakresu jego oddziaływania jako podmiotu wyposażonego we władztwo publiczne. Wśród ważnych czynników integrujących została wymieniona fachowość zarówno organów administracji publicznej na wszystkich szczeblach, jak i podmiotów odpowiedzialnych za stanowienie prawa. Ich biegłość w obcowaniu z prawem administracyjnym stanowi rękojmię poszanowania gwarancji konstytucyjnych, doboru właściwych metod i technik legislacji, a także nienadużywania prawa. Strażnikami integralności prawa administracyjnego przez wykładnię i stosowanie prawa pozostają również wyspecjalizowane sądy administracyjne. Wspólnym mianownikiem bądź też łącznikiem opisanych elementów są aksjomaty prawa administracyjnego.

$\mathrm{W}$ rozdziale czwartym zatytułowanym: Elementy sprzyjajace wewnętrznemu integrowaniu sie prawa administracyjnego (perspektywa prawa pozytywnego) Iwona Niżnik-Dobosz przenosi te rozważania na grunt prawa pozytywnego. Jest to jeden z najmniej ,eseistycznych” fragmentów publikacji. Tytułową integralność prawa administracyjnego autorka przybliża nie przez tworzenie własnej definicji tego pojęcia, ale w formie klarownej i wyrazistej tezy (s. 81), zgodnie z którą:

prawo administracyjne w swym bezsprzecznym rozczłonkowaniu [...] stanowi jedną względnie uporządkowaną i spójną ustrojowo, materialnie i proceduralnie całość/gałąź prawa, która m. im. dzięki celom, zasadom, instytucjom i pojęciom prawnym wyrażonym w prawie pozytywnym, w tym przede wszystkim Konstytucji RP, posiada nie tylko atrybuty uporządkowanej według pewnych kryteriów całości, ale także potencjalną zdolność do swoistego procesu scalania się (integrowania) w gałąź prawa.

Zgodnie z przyjętym założeniem w rozdziale przedstawiono kolejno elementy prawa pozytywnego świadczące o wewnętrznym zintegrowaniu przepisów prawa administracyjnego. Po raz kolejny podkreślona została rola Konstytucji jako głównego czynnika integrującego. Obserwacja ta została wzbogacona o refleksje dotyczące zasady zrównoważonego rozwoju i zasady proporcjonalności jako wyznaczników merytorycznego administracyjnoprawnego regulowania sfer życia społecznego, a także roli Konstytucji we wprowadzaniu i zabezpieczeniu standardów międzynarodowych. W tym miejscu godzi się podkreślić, że jest to pierwszy głos w publikacji przedstawiający prawo Unii Europejskiej jako część składową krajowego porządku prawnego, a nie jedynie pewien element „zewnętrzny” i przez to „dezintegrujący” prawo administracyjne. Normy konstytuujące pełnią także funkcję integrującą $\mathrm{w}$ zakresie, $\mathrm{w}$ jakim normują ustrój administracji publicznej (,integracja poprzez pojęcie organu”) i procedurę administracyjną. $\mathrm{Na}$ kolejnym poziomie szczegółowości w ocenie autorki na pozytywnoprawne czynniki integrujące składają się: zasady prawa, zasady techniki prawodawczej (rozumiane jako stypizowane, powtarzalne metody oddziaływania na rzeczywistość), gromadzenie i przepływ informacji, definicje ustrojowe pojęć, informatyzacja oraz system kontroli tworzenia, stosowania i egzekwowania prawa. Integracja na- 
stępuje także przez naturalne i obiektywne związki przyczynowo-skutkowe między przedmiotem regulacji. Jako przykład takiego powiązania wskazano między innymi relację między inwestycją budowalną i prawem budowlanym a kolejno prawem zagospodarowania przestrzennego, prawem ochrony środowiska i prawem wodnym. Wyróżniono także czynniki integrujące na gruncie ustaw szczególnych w postaci decyzji i pozwoleń zintegrowanych oraz tak zwanych ustaw wiodących, zawierających ogólne zasady i przepisy prawa administracyjnego. Choć te ostatnie pozostają jedynie $\mathrm{w}$ fazie projektów, to właśnie one mogą w przyszłości stanowić pozytywnoprawne spoiwo prawa administracyjnego.

Rozdziały piąty i szósty mają analogiczną strukturę, to jest zawierają analizę elementów przeszkadzających wewnętrznemu integrowaniu prawa administracyjnego odpowiednio z perspektywy teoretyczno- i pozytywnoprawnej. Rozdział autorstwa Aleksandry Puczko rozpoczyna problematyka niejednorodności prawa administracyjnego. Integralność jest przedstawiona jako wartość i cel na równi z trwałością i pewnością prawa, co jest nawiązaniem do Radbruchowskiej triady idei prawa. Heterogeniczność prawa administracyjnego prowadzi do pluralizmu chronionych wartości, co rodzi pytanie o funkcjonowanie takiego stanu rzeczy przy jednoczesnym poszanowaniu praworządności. Interesujące jest to, że autorka jako pierwsza bezpośrednio nawiązuje do integralnej teorii prawa Dworkina i idei „czystego prawa”. Prawo administracyjne przedstawia natomiast jako sposób administrowania, nie zaś jego podstawę. Autorka dokonała podziału „elementów przeszkadzających" na dwie kategorie. Pierwsza z nich to elementy przeszkadzające na poziomie aksjologicznym. Dokonując klasyfikacji wartości prawa administracyjnego, nawiązano do zaproponowanego przez Zimmermanna podziału na wartości uniwersalne (właściwe całemu systemowi prawa), wewnętrzne (tworzone przez samo prawo administracyjne) i te, dla których prawo administracyjne jest tworzone. Źródłem dezintegracji prawa administracyjnego są kolizje między wartościami chronionymi interesem ogólnym a interesem indywidualnym, a także różnice $\mathrm{w}$ optyce organu dokonującego wyboru w obliczu równoważnych wartości. Innym przykładem jest kolizja między wartościami chronionymi przez prawo Unii Europejskiej a prawem krajowym, choć jak się wydaje, ta ma co do zasady charakter pozorny. Druga kategoria to elementy przeszkadzające na poziomie norm i źródeł norm prawa. Ponownie poruszona zostaje kwestia wielości interesów i polaryzacji prawa administracyjnego. Wyodrębnianie prawa ustrojowego zostało ocenione jako nieprzydatne, zwrócono też uwagę na zjawiska takie jak „przerost proceduralny” i wzrastającą rolę ,,atypowych” źródeł prawa, na przykład zwyczaju. Ponownie jako czynniki dezintegrujące prawo administracyjne zostały wskazane multicentyczność źródeł prawa, niedoskonałości stosowania prawa, a także nadmierna kazuistyka i luzy decyzyjne. Na uwagę zasługuje zwłaszcza podsumowanie rozdziału, w którym autorka zauważa, że samo występowanie czynników przeszkadzających integralności nie jest zjawiskiem negatywnym 
i świadczy o bogactwie prawa administracyjnego i jego zdolności do płynnego adaptowania się do zmieniającej się rzeczywistości społecznej.

Rozdział szósty, Elementy przeszkadzająe $w$ wewnętrznym integrowaniu sie prawa administracyjnego (perspektywa prawa pozytywnego), został przygotowany przez Justynę Lemańską. Inaczej niż jej poprzednicy we wstępie podaje ona w wątpliwość, czy prawidłowe jest klasyfikowanie prawa administracyjnego jako odrębnej gałęzi. Autorka dzieli elementy przeszkadzające na pierwotne i pochodne, opierając się na założeniu, że dezintegracja na poziomie dogmatycznym przekłada się na brak integralności na poziomie prawa pozytywnego. Wiele miejsca poświęca elementom sprzyjającym dezintegracji administracyjnego prawa pozytywnego na etapie stanowienia prawa. Zostały do nich zaliczone problemy związane z dynamiką zmian prawa administracyjnego, jakością źródeł legislacji i wprowadzaniem instytucji prawa administracyjnego do prawa pozytywnego. To ostatnie działanie prowadzi do instrumentalizacji prawa i posługiwania się poszczególnymi instytucjami w ramach wąskich dziedzin regulacji, nieraz $\mathrm{z}$ całkowitym pominięciem kontekstu systemowego. Jako odrębne zagadnienie omówione zostały problemy rozstrzygania przez ustawodawcę charakteru sprawy i relacji prawa administracyjnego z prawem cywilnym. Przepisy kolizyjne, określające zakres spraw administracyjnych i definiujące sprawę cywilną, zakwalifikowano jednocześnie jako czynnik rozgraniczający i dezintegrujący, z uwagi na szerokie rozumienie sprawy cywilnej w ujęciu formalnym, obejmującym sytuacje, w których zdarzeniem wywołującym skutki cywilnoprawne jest decyzja administracyjna. Kolejny czynnik to problem dezintegracji interdyscyplinarnej. Pod tym pojęciem należy rozumieć wysoki stopień specjalizacji subdyscyplin takich jak prawo ochrony środowiska i administracyjne prawo medyczne. Przejawem tego zjawiska jest w szczególności postępująca fachowość języka prawnego, co prowadzi do dezintegracji ,pozasystemowej” prawa. Następny element to heterogeniczność prawa administracyjnego. Jak już wskazano, autorka przyjmuje jako punkt wyjścia prawo administracyjne jako system zdezintegrowany. Stan ten jest częściowo porządkowany przez wprowadzanie ustaw wiodących (prawo wodne, prawo budowlane), lecz niektóre węzłowe akty, z uwagi na swój przedmiot i cele regulacji, z konieczności zawierają równocześnie normy prawa karnego, cywilnego i administracyjnego (prawo nieruchomości). Krytycznie odniesiono się do problemu kodyfikacji prawa administracyjnego, w szczególności prawa materialnego i ustrojowego. Autorka stoi na stanowisku, że integrująca rola prawa procesowego ma jedynie charakter pozorny, czego dowodzi praktyka, jak również sam fakt koegzystencji kodeksu postępowania administracyjnego i Ordynacji podatkowej. Odwołując się do podziału postępowań szczególnych na autonomiczne i nieautonomiczne według Janusza Borkowskiego, Lemańska podaje w wątpliwość, czy jednolitość postępowania administracyjnego jest w ogóle pożądana, czy tak naprawdę w płaszczyźnie prawa pozytywnego mamy do czynienia z systemem praw postępowań administracyjnych. 
Uwagi dotyczące dezintegracji na etapie stosowania prawa mają bardziej ogólny charakter. Stwierdzono, że niedoskonałości ustawodawcy nie mogą obarczać organów administracji i wymuszać kreowania rozwiązań ad hoc w sytuacjach problemowych. Zwrócono uwagę na kwestie takie jak niejednorodność linii orzeczniczych i nieprzygotowanie administracyjne sędziów. Pewne wątpliwości może budzić stwierdzenie, że instytucjami osłabiającymi bezwzględne obowiązywanie norm prawa administracyjnego i jego integralność są mediacje i ugody.

Najobszerniejszą, trzecią część monografii poświęcono zagadnieniom szczegółowym dotyczącym integralności zewnętrznej prawa administracyjnego. W rozdziale siódmym Mariusz Oleś raz jeszcze podejmuje problematykę granic prawa administracyjnego i jego pogranicza. W jego ocenie przyjęcie, że prawo administracyjne jest gałęzią prawa, implikuje, iż jest zintegrowane wewnętrznie, natomiast ,integralność prawa administracyjnego zakłada, że prawo to stanowi pewną całość wyznaczoną przez swoiste kryteria lub znamiona" (s. 144). Kryteria wyodrębniania prawa administracyjnego są względne. Granice także mają różną długość i szczelność, ponadto są różnie postrzegane w zależności od tego, czy mówimy o gałęzi prawa, dyscyplinie naukowej lub dydaktycznej. Refleksja nad granicami i pograniczem w ujęciu aksjologicznym jest niewystarczająco precyzyjna i wielopostaciowa, możemy bowiem wyróżnić ujęcie historyczne i bieżące, kontekst pionowy i poziomy (głębokość źródeł prawa, zakres przedmiotowy), kwestię jednolitości jurysdykcji, a także ujęcie pozytywnoprawne.

Przechodząc do konkretnych przejawów funkcjonowania pogranicza prawa administracyjnego, wskazano w szczególności na zjawisko współstosowania norm prawa administracyjnego i innych gałęzi prawa. Tworzenie przepisów z obszaru to także integracyjna i międzygałęziowa metoda ochrony wartości, czego przykładem jest walka polskiego ustawodawcy z wprowadzaniem do obrotu tak zwanych dopalaczy. O pograniczu możemy mówić również w przypadku wielotorowego reżimu odpowiedzialności, tak jak ma to miejsce w prawie budowlanym, w którym poszczególne naruszenia obłożone są jednocześnie sankcją administracyjną i traktowane jak przestępstwa skarbowe. Autor trafnie zwraca uwagę, że celem niektórych przepisów administracyjnych jest dopełnienie innych gałęzi prawa. Potwierdza to między innymi stosunek przepisów o miejscowym zagospodarowaniu przestrzennym względem prawa własności. Podobnie do obszaru pogranicza należy zakwalifikować międzygałęziowe skutki prawa administracyjnego, takie jak decyzja o wywłaszczeniu nieruchomości czy użytkowanie wieczyste. Dość szeroko odniesiono się także do zagadnienia samodzielności jurysdykcyjnej organów administracji publicznej i sądów administracyjnych z uwzględnieniem jego doniosłości dla praktyki stosowania prawa administracyjnego.

Rozdział ósmy autorstwa Joanny Człowiekowskiej dotyczy powiązań między prawem administracyjnym a prawem konstytucyjnym. Jest to fragment o wyraźnie przeglądowym charakterze. Odrębnie zostały omówione relacje wewnętrzne (odśrodkowe) i zewnętrzne między gałęziami prawa. W odniesieniu do relacji 
zewnętrznych przywołany został dorobek Jerzego Stefana Langroda, Franciszka Longschampsa de Bérier, Jana Bocia i Tadeusza Kuty. Przytoczone zostały także stanowiska doktryny (między innymi Janusza Łętowskiego, Eugeniusza Ochendowskiego i Jana Zimmermanna) dotyczące swoistości regulacji prawa administracyjnego, które nie pozwalają zaakceptować poglądu, jakoby prawo administracyjnego mogło stanowić jedynie przedłużenie prawa konstytucyjnego o wyższym stopniu szczegółowości. Tym samym ustalenie, że prawo administracyjne i prawo konstytucyjne są odrębnymi gałęziami prawa, implikuje zasadność ustalenia granic między nimi. Ilustrując przebieg tych granic, Człowiekowska posłużyła się metaforą gmachu prawa. W perspektywie relacji wewnętrznych autorka wskazuje, że spójność systemu prawa uzasadnia wzajemne oddziaływanie na siebie jego gałęzi - katalog źródeł prawa administracyjnego musi być zgodny z konstytucyjną, konstytucyjne umocowanie mają także normy o podstawowym znaczeniu dla prawa administracyjnego, w tym zasada pomocniczości i decentralizacja administracji publicznej. Konstytucja tworzy dla prawa administracyjnego kontekst interpretacyjny. Pozytywnie należy ocenić odwołanie się także do poglądów polemicznych, a dokładnie do Wojciecha Orłowskiego, według którego prawo konstytucyjne i administracyjne oddziałują na siebie „ornamentacyjnie” i nie ma między nimi kompatybilności. Przeprowadzona analiza literaturowa pozwoliła na wyciągnięcie wniosku, że związki między omawianymi gałęziami są wielowymiarowe - w płaszczyźnie zewnętrznej dąży się do integralności obu gałęzi, a w płaszczyźnie wewnętrznej integruje je przez wartości i zasady konstytucyjne.

W rozdziale dziewiątym Ewa Skorczyńska podejmuje tematykę pogranicza administracyjno-cywilnego. Relacja między tymi gałęziami została przedstawiona od strony teoretycznej i uzupełniona o przykłady praktyczne. Rozdział zawiera liczne odwołania do literatury przedmiotu. Wskazano, że pogranicze wymaga refleksji nad kryteriami delimitacji poszczególnych dziedzin, co było przedmiotem, zainteresowania autorów powojennych (wspomnianych Langroda i Longschampsa, a także Emanuela Iserzona i Józefa Litwina). Punktem odniesienia do oceny ich dorobku jest natomiast klasyczny podział na prawo publiczne i prywatne. Opisane zostały kolejno teorie relacji między prawem cywilnym i administracyjnym: teoria dwóch metod Tadeusza Hilarowicza, teoria współzależności systemów Litwina, teoria różnicy stopnia (nastawienia) Langroda, teoria wyjątku Longchampsa, teoria funkcjonalnego związku Ulpiana i teoria służby publicznej Wszołka. Druga część pracy dotyczy przykładowych problemów pogranicza. Pośród nich omówiono następstwo prawne w zewnętrznych stosunkach administracyjnoprawnych, problematykę umów administracyjnoprawnych, nadużycie prawa i odpowiedzialność odszkodowawczą za legalne działania administracji.

W rozdziale dziesiątym Dorota Dąbek zajęła się obszarem pogranicza prawa administracyjnego i prawa karnego. Autorka w sposób precyzyjny, usystematyzowany i wyczerpujący opisała różne aspekty tego zagadnienia. Przytoczone zostało podstawowe orzecznictwo międzynarodowe dotyczące rozgraniczania kary 
kryminalnej od sankcji administracyjnej. Na tym tle przedstawiono aktualną problematykę wyróżniania w piśmiennictwie sankcji formalnie administracyjnych. Dąbek stanowczo opowiada się przeciwko traktowaniu tych kar pieniężnych jako sankcji „trzeciej kategorii” kar. Przekonująco argumentuje, że sam fakt tożsamości dolegliwości, które niosą z sobą grzywny karne i administracyjne kary pieniężne, nie uprawnia analogii do prawa karnego czy wręcz hybrydowego stosowania zasad rządzących tą gałęzią prawa. Omówiono także główne skutki wynikające z faktu istnienia pogranicza. Pierwszy z nich to pozorna konkurencyjność sankcji, ponieważ penalizacja czynu równolegle z podstawy administracyjnej i karnej nie narusza zasady ne bis in idem. Po drugie, istnienie pogranicza sprzyja dekryminalizacji sankcji karnych ze względu na łatwiejszą egzekucję sankcji administracyjnych. Uwagi dotyczące tej ostatniej kwestii skłaniają do refleksji, czy jest to pożądany kierunek rozwoju regulacji ujemnych zjawisk społecznych. Autorka przedstawia także propozycje działań wzmacniających granice między omawianymi gałęziami prawa, tłumacząc jednocześnie, dlaczego jest to potrzebne z punktu widzenia praw jednostki. Należy w pełni zgodzić się z przedstawionym postulatem zmian legislacyjnych, kierujących do wprowadzenia minimalnych standardów administracyjnoprawnej regulacji sankcji o karnym charakterze.

Tytuł kolejnego rozdziału to Prawo administracyjne a dziedziny z niego wyroste. Autor rozdziału, Piotr Dobosz, przeprowadził analizę prawa administracyjnego, którą można określić jako introspekcję heterogeniczności tego prawa. Główną myślą opracowania jest założenie, zgodnie z którym specjalizacja przedmiotowa w poszczególnych obszarach prawa administracyjnego doprowadziła do wykształcenia się dziedzin, które tworzą jego system. Związki poszczególnych dziedzin z ogólnym prawem administracyjnym mają różny stopień intensywności. Niektóre dziedziny czy subdyscypliny bywają wyłączane jako odrębny przedmiot poznania dla celów akademickich i procesowych, jednak w ocenie autora nie zmienia to faktu, że wspólnie kształtują integralny system. Uprawnione jest zatem zaliczenie do systemu prawa administracyjnego także prawa procesowego. Jako dyskusyjne należy jednak ocenić włączenie w poczet systemu prawa administracyjnego także prawa gospodarczego ${ }^{2}$. Po raz kolejny zwraca też uwagę swoiste „oddolne” klasyfikowanie prawa Unii Europejskiej jako odrębnej gałęzi prawa. Skutkuje to w mojej ocenie nadmiernie uproszczonym przedstawianiem powiązań między prawem krajowym a prawem unijnym i niepotrzebnie zawęża pole dyskusji nad zjawiskiem integralności.

Szczegółowym relacjom między prawem administracyjnym a prawem Unii Europejskiej poświęcony został rozdział dwunasty autorstwa Marty Kisielowskiej. $Z$ jednej strony powiela on tezę o dezintegrującym wpływie multicentryczności źródeł prawa na system prawa administracyjnego. Jednak z drugiej strony autorka

2 W. Małecki, Policja gospodarcza w prawie gospodarczym. Ujęcie teoretyczne, Warszawa 2019. 
przywołuje - wciąż potrzebny w dyskusji nad rolą norm prawa ponadnarodowego - głos Langroda:

Można sobie co prawda wyobrazić sytuację, w której oddziaływanie to byłoby i bezpośrednie, tzn. wejście treści takiej konwencji — poprzez ustawę ratyfikacyjną — wprost w skład wewnętrzno-państwowego prawa administracyjnego, o ile konstytucja, lub poszczególne ustawy, wiązałyby z ratyfikacją skutki prawne także wewnątrz, albo o ile bezpośredniość tych skutków wynikałaby ewent. wprost z traktatu międzynarodowego. Stając się jednak, ewent. nawet wprost, jego częścią składową, nie tworzyłyby one i tak w obrębie prawa administracyjnego osobnego działu jego reguł „międzynarodowych”, ale wchodziłyby od razu w skład tych działów tego prawa, do których ze względu na swoją treść przynależą ${ }^{3}$.

Pogłębione przedstawienie tego zagadnienia przez autorkę stanowi dobrą przeciwwagę dla reszty publikacji, w której system prawa europejskiego został przedstawiony — być może nieumyślnie — jako swoisty extraneus. Opracowanie Kisielowskiej dobrze oddaje wielopłaszczyznowość oddziaływania prawa unijnego na teorię i praktykę prawa administracyjnego — pod względem zarówno pozytywnym, jak i negatywnym. Dużą zaletą rozdziału jest wieloaspektowe ujęcie relacji z prawem unijnym w procesie stosowania prawa. Autorka zwróciła uwagę przykładowo na skutki wielojęzycznego stanowienia prawa, których pokłosiem jest orzeczenie TSUE w sprawie Skoma-Lux.

W zakończeniu publikacji znalazła się praca o charakterze polemicznym. W rozdziale trzynastym Mariusz Krawczyk zastanawia się, czy występowanie zjawisk ekspansji i ustępowania prawa administracyjnego z określonych pól regulacji świadczy o ofensywności, czy też defensywności tego prawa. Pytanie badawcze zostało zweryfikowane w różnych kontekstach granicznych prawa administracyjnego. Autor wyróżnił też cztery podstawowe przejawy omawianego zjawiska: całkowite ustępowanie prawa administracyjnego z określonych pól regulacji; częściowe zastępowanie norm prawa administracyjnego przez mechanizmy innych gałęzi prawa; wkraczanie zasad i reguł prawa administracyjnego w zakres pozyskany od innej dziedziny lub wcześniej z nim niezwiązany; wykorzystywanie odrębnych komponentów przez prawo administracyjnego do realizacji jego własnych założeń. Wśród przykładów przywołanych zjawisk omówiono między innymi zagadnienie defensywności prawa karnego, zdaniem autora mającej charakter jedynie pozorny. Zwrócono też uwagę na relatywnie nowe dyscypliny, w których wartości prywatnoprawne chronione są mechanizmami prawnoadministracyjnymi, czego doskonały przykład stanowi prawo ochrony danych osobowych. Należy zgodzić się z autorem, że zaproponowane kategorie ofensywności i defensywności pozwalają uchwycić aspekt dynamiczny integracji zewnętrznej prawa administracyjnego i przedstawić ją nie jako stałą wartość, lecz jako proces. Krawczyk pośrednio ukazuje nam więc kolejną interpretację pojęcia integralności.

3 J.S. Langrod, Instytucje prawa administracyjnego. Zarys części ogólnej, Kraków 2003, s. $80-81$. 
Przechodząc do podsumowania pracy jako całości, nie można odmówić jej przedstawienia tytułowego zagadnienia w sposób wielowymiarowy. Różnorodność i wielowątkowość (także w obrębie poszczególnych rozdziałów) sprawia, że koncepcja integralności stanowi raczej myśl przewodnią niż temat pracy. Nie można mieć o to pretensji do autorów, zostało to bowiem wyraźnie zaznaczone we wstępie. W miarę lektury odkrywamy, że przedmiotem publikacji nie jest przedstawienie wyczerpującego zbioru postulatów metodologicznych, lecz że stanowi ona zbiorową próbę ich zastosowania do opisu polskiego prawa administracyjnego. Jest to bardzo ciekawa i potrzebna inicjatywa, która może przyczynić się do ugruntowania tożsamości metodologicznej prawa administracyjnego. Dzięki temu jawi się jako zjawisko pożądane, ponieważ — posługując się słowami Jana Jeżewskiego

Tożsamość metodologiczna nauki nie oznacza bowiem zamknięcia jej granic poznawczych; między nowymi obszarami badań a metodami badawczymi istnieje ścisły związek polegający na dostosowaniu, czyli w pewnym zakresie rewizji aparatury badawczej, która umożliwia nie tylko uzyskanie, ale także sensowne włączenie wyników badań w ramy dotychczasowego dorobku tej dyscypliny ${ }^{4}$.

Omawiana praca została zamknięta w ramach „perspektywy polskiej”, co sprawia, że uczynienie jej przystępną dla zagranicznego czytelnika nie jest zadaniem łatwym. Pierwszą przeszkodę napotykamy w samym tytule. Dokonując przekładu na język angielski, zdecydowano się na przetłumaczenie słowa integralność jako integrity. Wybór ten jest uzasadniony odwołaniem się autorów do pozytywistycznego rodowodu tego pojęcia i teorii integralnego prawa Ronalda Dworkina. W oryginałach prac Dworkina pojęcie to funkcjonuje w zbliżonym (choć zdecydowanie nie tożsamym) znaczeniu (integrity in law, integrity in legislation, integrity in adjudication ${ }^{5}$ ). Inne umocowanie dla tego terminu znajdziemy, nawiązując chociażby do zasady nienaruszalności terytorium w prawie publicznym międzynarodowym (principle of territorial integrity).

Nie można jednak tracić z pola widzenia, że pierwsze znaczenia słowa integrity to prawość i uczciwość. W aktach prawnych i publikacjach jest ono często używane w znaczeniu odnoszącym się do etyki, prawa antykorupcyjnego i odpowiedzialności funkcjonariuszy publicznych. Może to być o tyle mylące dla anglojęzycznego czytelnika, że — jak wspomniano na początku — dla dwóch wydań książki nie przewidziano odrębnych wstępów. Wobec tego ma on realną szansę poznać zakres tematyki książki dopiero po lekturze pierwszego rozdziału. Po uwzględnieniu tego zastrzeżenia niefortunny zdaje się ustęp rozdziału pierwszego dotyczący semantycznej analizy pojęcia, który został przetłumaczony w sposób dosłowny, z całkowitym pominięciem rzeczywistego anglojęzycznego ekwiwa-

4 J. Jeżewski, ,Administracja Unii Europejskiej. Zagadnienia wybrane”, Jerzy Supernat, Wroclaw 2013. Recenzja, „Administracja. Teoria - dydaktyka - praktyka” 2013, nr 2, s. 92.

5 Zob. R. Dworkin, Law's Empire, Cambridge 1986, s. 217. 
lentu tego słowa. Na szczęście fragment ten zawiera zaledwie dwa akapity i nie zmienia sensu samego rozdziału.

W trakcie lektury da się odczuć, że thumaczenie poszczególnych części było dokonywane przez różne osoby. Dowodzą tego znaczne rozbieżności w sposobie przytaczania aktów prawnych i orzecznictwa - na przestrzeni całej książki są one przekładane w całości (z przyjęciem różnych konwencji), w części lub zupełnie pomijane. Zdarzają się także przypadki niekonsekwencji terminologicznej, i to w obrębie samych rozdziałów. Wersja anglojęzyczna nie jest też wolna od błędów gramatycznych i stylistycznych, typowych przy wykonywaniu dosłownej translacji wersji polskiej. Powyższe uwagi można sprowadzić do ogólnego „zarzutu”, jakim jest to, że publikacja w języku angielskim jest typowym tłumaczeniem (nie zaś pracą przygotowaną $\mathrm{w}$ języku angielskim) i podczas jego tworzenia niewielką uwagę przywiązano do ekwiwalencji formalnej tekstu.

Nie oznacza to, że praca staje się przez to niezrozumiała lub nie przedstawia wartości dla niewładającego językiem polskim czytelnika. Należy jednak pamiętać, że już sama konstrukcja monografii (wielość i szczegółowość poruszanych tematów) stawia przed czytelnikiem dość wysokie wymagania w zakresie znajomości polskiego systemu prawa, a także jego aktualnych problemów, a chwilami nawet ogólnej znajomości dorobku przedstawicieli doktryny. Przykładowo z uwagi na brak informacji wprowadzających i dodatkowych przypisów niejasne mogą być rozważania dotyczące prawa o wykroczeniach, które w wielu państwach stanowi po prostu część systemu prawa administracyjnego. Opisane niedoskonałości obniżają sugestywność wielu zawartych w książce praktycznych przykładów, gdy autorzy posługują się instytucjami swoistymi dla prawa polskiego, takimi jak użytkowanie wieczyste. Konieczność zmierzenia się z tymi trudnościami zawęża grono potencjalnych czytelników tej pozycji w języku angielskim, lecz nie obniża jej wartości poznawczej dla badaczy polskiego prawa administracyjnego. 